\title{
Using 18th century storm-surge data from the Dutch Coast to improve the confidence in flood-risk estimates
}

\author{
F. Baart ${ }^{1,2}$, M. A. J. Bakker ${ }^{3}$, A. van Dongeren ${ }^{2}$, C. den Heijer ${ }^{1,2}$, S. van Heteren ${ }^{3}$, M. W. J. Smit ${ }^{4}$, M. van \\ Koningsveld ${ }^{1,5}$, and A. Pool ${ }^{6}$ \\ ${ }^{1}$ Delft University of Technology, Faculty of Civil Engineering and Geosciences, Delft, The Netherlands \\ ${ }^{2}$ Deltares, Delft, The Netherlands \\ ${ }^{3}$ Geological Survey of the Netherlands (TNO), Utrecht, The Netherlands \\ ${ }^{4}$ Netherlands Institute of Ecology, Centre for Estuarine and Marine Ecology (NIOO CEME), Yerseke, The Netherlands \\ ${ }^{5}$ Van Oord Dredging and Marine Contractors, Rotterdam, The Netherlands \\ ${ }^{6}$ Jelmer, Vinkeveen, The Netherlands
}

Received: 23 May 2011 - Revised: 25 July 2011 - Accepted: 26 July 2011 - Published: 20 October 2011

\begin{abstract}
For the design of cost-effective coastal defence a precise estimate is needed of the $1 / 10000$ per year storm surge. A more precise estimate requires more observations. Therefore, the three greatest storm surges that hit the northern part of the Holland Coast in the 18th century are reconstructed. The reconstructions are based on paintings, drawings, written records and shell deposits that have recently appeared. The storm-surge levels of these storms have been estimated using numerical modelling of the coastal processes. Here we show how these reconstructions can be used in combination with extreme value statistics to give a more confident estimate of low probability events.
\end{abstract}

\section{Introduction}

Coastal and river flooding are the main natural hazards in the Netherlands. To reduce flooding risks, primary sea- and river-defence systems (i.e. dunes and dykes) must have minimum crest level and width as defined in periodic assessments based on monitoring and modelling data. Since the last major coastal flood in the Netherlands in 1953, dunes and dykes have been raised to and are maintained at levels allowing these primary defence systems to withstand storm surges with probabilities of 5/10000-1/10000 per year. The higher the economic value of the hinterland, the lower the probability

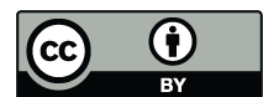

Correspondence to: F. Baart

f.baart@tudelft.nl of the maximum extreme event used to define the crest level and width of dunes and dykes. In 2009 the law was amended so that each dyke ring had an exceedance probability for the whole dyke rather than per section.

The extreme safety standards reflect the vulnerability of the economically most valuable part of the Netherlands, which is mostly below sea level (van Dantzig, 1956; Deltacommissie, 1960). Working with such extremely low exceedence probabilities presents a number of statistical challenges, as tide-gauge records are at most three centuries long. The most extreme storm-surge events are likely not represented in these records. To quantify such extreme storm surges, the distribution of observed surges as distilled from tide-gauge records is extrapolated by applying extreme value statistics (de Haan, 1990; Coles, 2001). Using this technique, an estimate can be given of various properties of the $1 / 10000$ per year storm. The surge is the most important of these properties when assessing the safety afforded to the Dutch lowlands by the fronting coastal dunes (van de Graaff, 1986).

The effective design of the coastal defence depends on how high a $1 / 10000$ per year storm surge will be, but this is not precisely known. Using extreme value statistics, van den Brink et al. (2004) showed that the confidence interval of the $1 / 10000$ per year surge is between 2.9 and $6.5 \mathrm{~m}$ for the Hoek van Holland station (Fig. 1). Using the upper limit of this rather large confidence interval $(3.6 \mathrm{~m})$ would likely lead to an unnecessarily expensive design of the coastal defence system. One could neglect the large confidence interval and just use the most likely estimate but it is undesirable to hide the uncertainty from the view of probabilistic engineers. A

Published by Copernicus Publications on behalf of the European Geosciences Union. 
better alternative would be to reduce the size of the confidence interval. This can be done by increasing the number of observations (the size of the confidence interval depends on $n^{-\frac{1}{2}}$, where $n$ is the number of observations) or by introducing other variables that reduce the error in the surge estimates. In this study, we focus on increasing the number of observations by adding data from discrete events described and analysed in historical records.

Previous studies on creating a more reliable estimate of the $1 / 10000$ per year storm surges have combined data from various sources. Storm surges for which data are available can be subdivided into four groups, on the bases of surge data availability.

Pre-historic. No measurements or written records are available. The effects of individual storms are traced back using geological records. Sedimentological analyses provide estimates of surge or run-up, but commonly the date of the storm cannot be constrained well. An example of a geological study on surge heights was published by Jelgersma et al. (1995), who concluded that storm surges of up to $5 \mathrm{~m}$ occurred in the past.

Historical storms. Written records and artworks are available and can be used to trace back the magnitude and impact of a storm. The date of the storm is usually known and the associated magnitude can be constrained from descriptions or from incidental measurements. No monitoring series of regular consistent measurements are available. Although the earliest records date from 838 AD (Buisman and Engelen, 1995), they become increasingly abundant (with multiple accounts for single events) from the 16th century onwards (Buisman and Engelen, 1996; Gottschalk, 1971). One disadvantage of using these older records is that the exact time of the peak water level is commonly missing. Therefore, the difference between the peak water level and the astronomical tide can not always be determined accurately. Peak water level, relative to mean sea level, is also a useful parameter, but introduces uncertainty when used in the prediction of exceedence levels. An example of late historical records are ship logs, used for example by Wheeler et al. (2010).

Measured storms. Series of measurements are available, collected by automated monitoring systems or by dedicated and trained officials. For the Dutch coast, the earliest tidal station in Amsterdam was installed in 1700. Most of the main stations along the North Sea coast that are still in use were installed during the late 19th century.

Modelled storms. Based on variable input data, series of models are run to create a wide variety of possible storms and associated surges. Van den Brink et al. (2004) used a dataset of seasonal forecast ensemble runs that were used as samples in an extreme value analysis. Because the confidence interval is dependent on sample size, they were able to reduce the interval from $3.6 \mathrm{~m}$ to $0.9 \mathrm{~m}$.

In this paper we focus on historical storms, more specifically the greatest storm surges along the Northern Holland coast of the 18th century. We combine the results with an analysis of measured data from the 20th century. Pooling historical records with measurement series has proved useful for estimating flood frequencies for return periods $>100 \mathrm{yr}$ in fluvial research (Macdonald et al., 2006). We do not include the 19th century because including this period requires a different approach. The romanticism movement and later the impressionism movement didn't result in paintings that are very useful for coastal reconstructions. Measurements from the 19th century are more prevalent but these need to be checked with special attention to possible errors and changes in vertical reference levels, for example. This extra effort makes the 19th century records an interesting topic for future research.

From a statistical view, combining information on storm surges from the 18th and 20th centuries implies that the storms from the 18th century are from the same "population" as the storms from the 20th century. The trend in storminess is sensitive to the area and period. For example, De Kraker (2005) found that there was no significant change in storm climate over the period $1400-1625$ for Southern Holland. Others (Smits et al., 2005; Vautard et al., 2010) found that if there had been a change in storminess it would have been more likely a decrease than an increase, based on the periods 1962-2002 and 1979-2008. The decrease can be partly attributed to increased surface roughness (for example due to urbanisation, growth of forests). Another important aspect is the relative sea-level rise. The sea-level rise along the Dutch coast has been constant since at least 1890 (Baart et al., 2011) and possibly longer (Jevrejeva et al., 2008). For this study, we assume a constant storminess and constant relative sealevel rise over the last century.

Several inventories of 18 th century extreme events provide a good collection of information. Extreme water levels and related flood marks (stones with inscriptions) were listed and discussed by Van Malde (2003) and numerous written records were assembled by Buisman and Engelen (2006). These inventories can be supplemented by information from historical paintings. An example of such an approach is given by Camuffo (2010), who used paintings of Venice (Italy) to determine a constant sea-level rise between 1700 and 2000. McInnes (2008) uses art to show coastal changes along the coast of the Isle of Wight (United Kingdom).

In this study we analyse historical paintings and drawings. In addition, we combine the analytical results with information obtained from geological records, field measurements and numerical models, to constrain the estimate of the $1 / 10000$ water level and the associated morphological effect. 
Table 1. Storm surges of the 18th century.

\begin{tabular}{lll}
\hline Year & Classification $^{\mathrm{a}}$ & Order $^{\mathrm{b}, *}$ \\
\hline 1715 & $\mathrm{D}$ & $5^{\mathrm{c}}$ \\
1717 & $\mathrm{D}$ & 3 \\
1741 & $/$ & $4^{\mathrm{d}}$ \\
1775 & $\mathrm{D}$ & $1^{\mathrm{e}}$ \\
1776 & $\mathrm{C}$ & $2^{\mathrm{f}}$ \\
\hline
\end{tabular}

* Because several different-sized inches were used in the 18th century (varying in length between 0.024 and $0.027 \mathrm{~m}$ ), it is not always clear what the exact metric translation is. Hence some of the notes below are given in inches. These values are only used to determine the ranking in the order column.

a Based on van Gelder (2000) A: very severe floods; B: heavy floods; C: less heavy floods; D: small floods.

${ }^{\mathrm{b}}$ For the North Holland coast

c In Amsterdam "0.31 m lower than 1717"; in Harlingen "9inches lower than 1717".

d In Amsterdam and Rheede the water level "has not been so high since 1717"; in Amsterdam"7inches lower than 1717"; "3inches less than 1717" (van Malde, 2003), no comparison with 1715 was found.

e In Amsterdam "as high as in 1717"; in Elburg "this flood is far higher than that of 1717"; in Delfshaven: flood stone: NAP +2.675 m (van Malde, 2003).

f Some reports indicate that this storm resulted in a higher surge than 1775 , for example in Beulake (village drowned in 1776), "1 feet higher than 1775", Delfshaven "higher than in 1775", flood stone: NAP +2.704 m(van Malde, 2003). On average for the northern Holland coast records, this storm was $0.2 \mathrm{~m}$ lower.

\section{The storm surges of the 18th century}

To be able to reduce the large confidence interval of the predicted $1 / 10000$ per year storm surge, it is insufficient to have observations or estimates of high surges, as it is unknown for which period and ordinal an individual surge is a representative value. Is it the biggest surge in a century or is it the second biggest surge in a decade? A fixed time window and an ordering of the storms are required to improve the estimate of the $1 / 10000$ per year water level.

To determine which storm surges are the three biggest, the ordering has to be found. Several studies of historical floods (Buisman and Engelen, 2006; van Gelder, 1996; van Malde, 2003) were used to determine the order of the storm surges. The time window used in this study is the 18th century and we try to estimate the three highest storm surges along the northern part of the Holland Coast. The two most severe storm events occurred in 1775 and 1776. The storm surge of 1715 is also designated as a moderately severe storm (van Gelder, 1996), but for the northern part of the Netherlands it was not so severe. For the study area the 1717 storm is ranked the third biggest of the 18th century as shown in Table 1.

For the three biggest storm surges $(1717,1775,1776)$ we reconstruct the peak water level. For the 1717 storm we use paintings as our main source. For the 1775 storm we use geological records. The 1776 storm surge is estimated on the basis of the average difference of reported water level from the 1775 and 1776 storms.

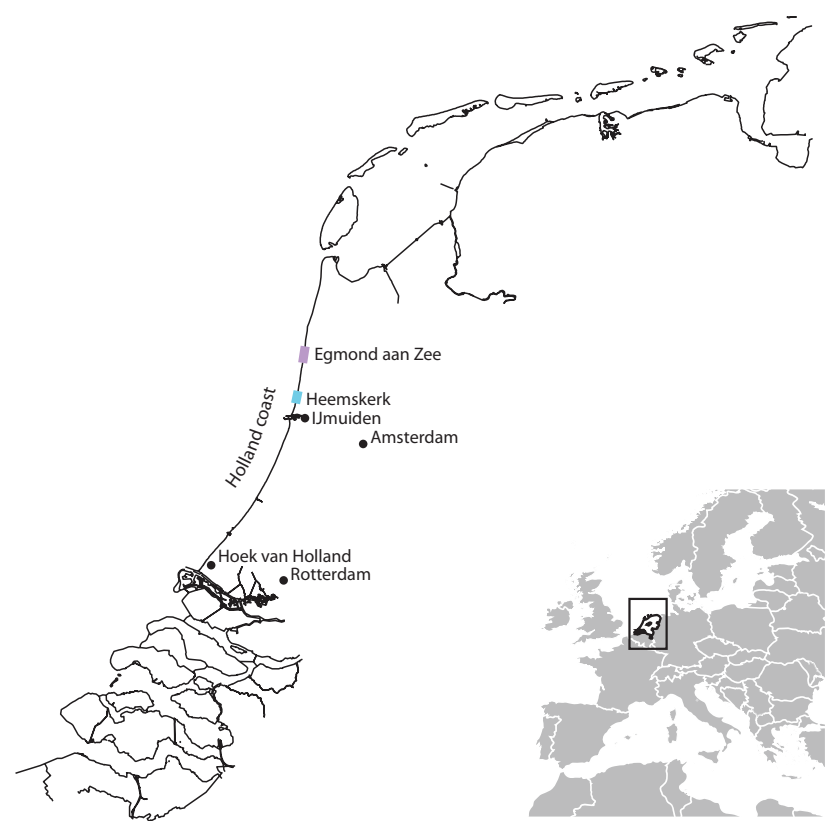

Fig. 1. Map of the locations mentioned in this paper. The Christmas flood of 1717 is analysed at the location of Egmond aan Zee. The 1775 storm is analysed at the Heemskerk location.

\subsection{Christmas flood 1717}

Lang and Homann (1963) recounted the conditions during the storm of 1717. An extract:

On the 25 of December, around lam, the NW storm increased rapidly and abruptly in strength until it formed a hurricane of such proportions that it seemed as if the earth was shaking. The sea was whipped to such an extent that several skippers reported that it was no longer possible to distinguish air and water. The hurricane lasted all night and did not lose much of its strength during Christmas Day. The evening was marked by severe thunder-, rain- and hailstorms. The storm kept blowing from the $N W$ direction [...] until the 26 of December. In the morning of Boxing Day the storm lost some of its strength, but around 3pm the storm regained some of its strength and brought a downburst with rain and hail. It was not until the 27 that the weather cleared and the sun reappeared.

The storm caused major floods in the northern Dutch provinces Friesland and Groningen, in northern Germany and in Denmark. Extensive damage reports were made after the storm (Extract van, 1717b). The number of victims exceeded 10000 . 


\subsubsection{Available data 1717 storm}

Because the damage and number of casualties were so great, the 1717 storm is well documented. Information about the characteristics of the storm and its effect can be found in incidental measurements, maps, one flood mark and historical records such as letters and poems. A brief overview of the historical records of the 1717 storm was given by Lang and Homann (1963). A very detailed analysis of the storm and the effects in Germany can be found in Jakubowski-Tiessen (1992). Associated surge levels are included in an inventory of storm surges made by Van Malde (2003). Temperature records are available through the Royal Netherlands Meteorological Institute (cf. Buisman and Engelen, 1995). Several documents provide narrative overviews and damage reports, including Nette aantekeningen (1717a); Extract van (1717b); Cramer von Baumgarten (1817); Bógaert (1719); Specht (1740); Schenk (1740); van Brussel (1776).

Focussing on our area of interest, the Northern Holland coast, and in particular on Egmond aan Zee (Fig. 1), paintings and drawings of Egmond beach, before and after the storm, were analysed to reconstruct the coast.

\subsubsection{Reconstruction 1717 storm surge}

Because there is such a large collection of paintings available for the 1717 storm, we were able to reconstruct pre- and poststorm profiles of Egmond beach.

The post-storm profile was measured on the 8 of February 1718 , just over a month after the storm. The measurement recorded the angles and elevations of the beach and the adjacent dune relative to mean high water.

Reconstructing the pre-storm profile required a combination of different data resources. Starting point was the analysis of a collection of paintings and drawings available of the Egmond aan Zee area between 1600 and 1700. A map of 1686 was used to determine the position of the church, the most prominent structure of the town, located near the beach. Most of the painters chose a view where at least the church tower was visible without obstructions. The church was positioned in a three-dimensional model of the coastal town. The paintings were aligned using the church as a reference point (Fig. 2). Structural coastal erosion can be seen in the fact that the paintings from the earlier part of the 17th century were painted from a vantage point farther from the coast than that of those from later times. The positioning of a series of pictures from 1620 in the 3-D model gives an estimate of the contemporary coastline. From comparing the 1686 map with reconstructions based on the older paintings, we estimate that the structural retreat of the coast was about $66 \mathrm{~m}$ in the period $1620-1686$, i.e. $1 \mathrm{~m}$ per year. This rate corresponds to the rate reported by de Ruig (1998). When using this rate to extrapolate the map of 1686 to 1717 , we obtain an estimate of the width of the dune top that would have been approximately $17 \mathrm{~m}$ (48 m in 1686 minus $31 \times 1 \mathrm{~m} \mathrm{yr}^{-1}$, see Fig. 2).
The beach width is assumed to be the same as that of the post-storm profile and the angles of the beach and dune are assumed to have been similar to the slopes from the average of that same area between 1963-1973 de Graaf et al., 2003, profile 7-3800 from the JARKUS dataset).

As no paleobathymetry information is available, both the pre- and post-storm profile up to mean high water are based on the bathymetry from the 1963 profile of the JARKUS dataset.

To get a rough estimate of the precision of the paintings, we analysed the intra- and inter-painter variance. As reference points we use the upper two parts of the Egmond aan Zee church tower. This steeple is present in 80 of the 96 paintings and drawings. The ratio between the height of the upper and second highest part of the steeple are determined for each image. The average ratio was 0.95 , with a standard deviation overall of 0.22 (Fig. 2). Images with ratios below 0.7 and above 1.2 were not included in the final analysis.

\subsubsection{Probabilistic modelling 1717 storm surge}

The pre-storm profile was used to set up an XBeach model (cf. Roelvink et al., 2009). XBeach is a morphodynamic model capable of capturing the physical processes in the nearshore that cause most of the coastline change during storm surges. The XBeach model uses the following parameters as input: water level, significant wave height, peak wave period, grain diameter and bathymetry/topography. The result of interest here is an estimate of the post-storm profile. Starting with the pre-storm profile, the XBeach model was run using different storm-surge levels. The surge levels, wave height and peak periods were drawn from the same distribution that is used for the safety-assessment method (WL I Delft Hydraulics, 2007). The storm-surge level with the erosion closest to the "observed" erosion was selected, as judged from the erosion volume.

This gave an estimated magnitude of 5/100 per year (Fig. 3), which corresponds to a water level of $3.1 \mathrm{~m}$ together with a significant wave height of $6.8 \mathrm{~m}$ and a peak period of $10.4 \mathrm{~s}$.

\subsection{The storm surge of 15 November 1775}

The largest storm surge of the 18th century was caused by the November 1775 storm. Buisman (1984) and Buisman and Engelen (2012) described the storm as follows:

In the late afternoon of 14 November and the night of 14/15 November, a severe WNW-NW storm raged accompanied by heavy rain, hail and thunder. Sea level rose higher than every flood before, especially higher than the severe storm surges of 1682 and 1717. [..] At the North Sea coasts, dune damage developed, e.g. near Terheyde and Scheveningen ("half of it covered by the sea"). Part of the Hondsbossche sea defence is destroyed. [..] Many ships were wrecked, especially on the 

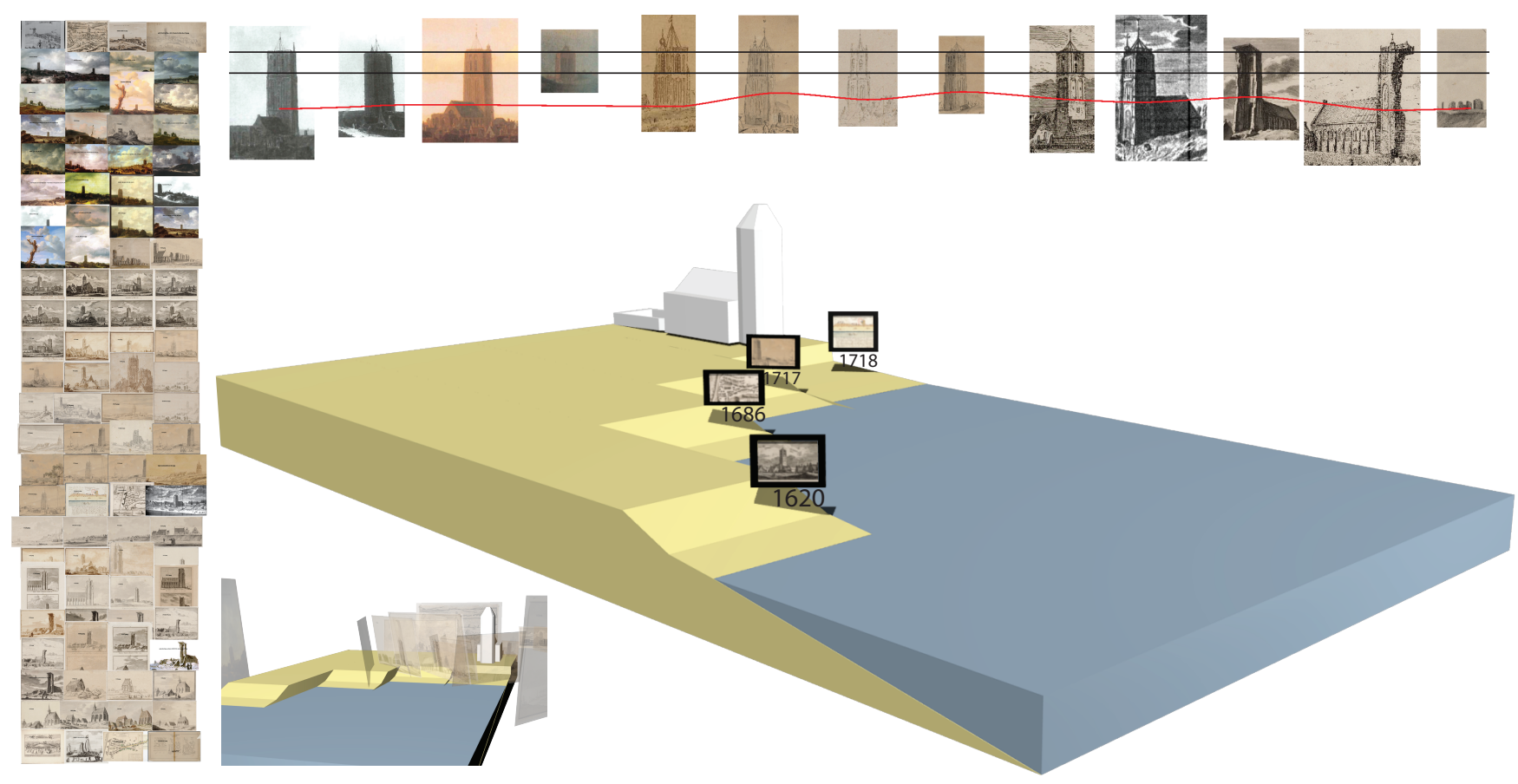

Fig. 2. Left: overview of the paintings and sketches used in the reconstruction. Top: determining the painter reliability by comparing the ratio between the upper two parts of the Egmond aan Zee church tower. Bottom: 3-D reconstruction of the coastal town of Egmond aan Zee. Center: four reconstructed profiles for the years (from front to back) 1620, 1686, 25 December 1717 and 8 February 1718.

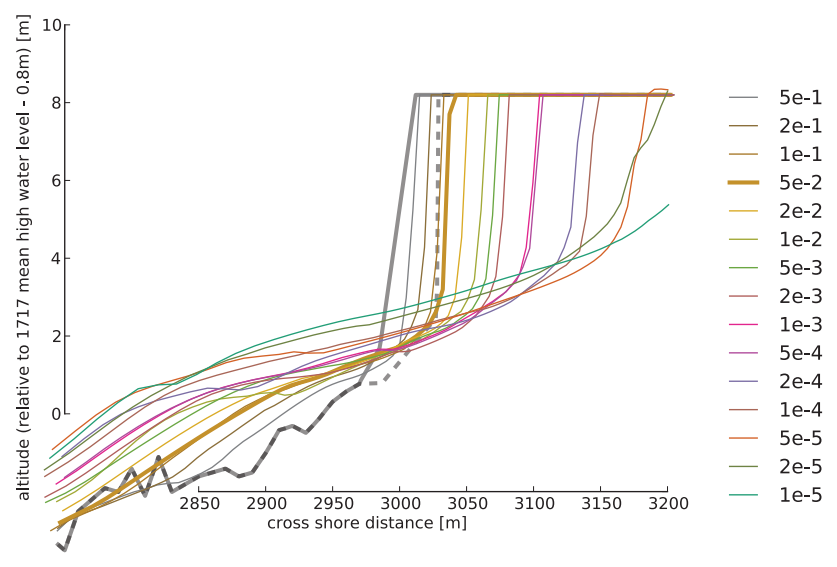

Fig. 3. Modelled and reconstructed profiles of the 1717 storm at Egmond aan Zee. Gray solid line: pre-storm reconstructed profile. Gray dashed line: post-storm reconstructed profile. Colored lines: modelled profiles. Thick colored line: modelled profile that best matches the pre- and post-storm reconstructions within the measured area with an occurrence probability 5/100 per year (return period $20 \mathrm{yr}$ ).

North Sea. "Along the entire beach one saw nothing but ship wrecks, rigging, cargo and bodies being washed to the shore." 200 Ships were lost!

\subsubsection{Available data 1775 storm}

More records exist for the 1775 storm than for the data for the 1717 storm. Unfortunately, the church at Egmond aan Zee was no longer available as a reference point for a 3-D reconstruction because the steeple fell into the sea during the storm surge of 1741. In 1746 a new church was built at the landward end of the village. Most of the relevant records for the 1775 event were gathered by interested individuals who made meteorological and hydrodynamic measurements. Historical records about morphology, such as the post-storm profile for 1717, are not known for this storm.

New useful evidence about the 1775 storm became available recently. After a storm surge hit the Dutch coast on 9 November 2007, old storm-surge deposits were discovered in the eroded dunes near Heemskerk (Fig. 1). These deposits were recognized as the remnants of one or two historical storm surges. The layers consisted of sand, shells and bricks. Details of the layers and the associated reconstruction were provided by Cunningham et al. (2011). Luminescence dating placed the storm-surge layers at the end of the 18th century (Cunningham et al., 2009). Major storm surges occurred in 1775 and 1776. The maximum observed water level in Petten (the location closest to Heemskerk with observations) was the same. Hence, no clear distinction was possible between the two storm surges. In the modelling used to reconstruct the storm, it was assumed that the deposits were from the 1775 storm surge (Pool, 2009). 
Table 2. Overview of available data per storm.

\begin{tabular}{lll}
\hline & 1717 & 1775 \\
\hline Wind & general path + duration & $3 x$ per day observations \\
Water level & Inundation map & Water levels in Petten \\
Grain distribution & No data & Grain distribution \\
& & from storm-surge layer \\
\hline
\end{tabular}

Other useful information used in to reconstruct the 1775 storm damage to the coast are the wind-force observations from $20 \mathrm{~km}$ south of Heemskerk (KNMI, 2011, maximum wind force 14 "noppen", 17.2-20.7 $\left.\mathrm{m} \mathrm{s}^{-1}\right)$, the maximum storm surge related water level recorded at Petten $(25 \mathrm{~km}$ north of Heemskerk, $2.8 \mathrm{~m}$ above the $1775 \mathrm{~m} . \mathrm{s} .1$ ) (van Malde, 2003) and the median grain diameter, as derived from a sieve analysis of sand in the deposits. The water-level observation comes from a 1793 report on the sea-defence system at Petten and is not accurate (Conrad, 1864). Conrad emphasized that the reference level used was about $1 \mathrm{~m}$ too high, requiring an upward correction of the surge level, and that open coast storm-surge measurements made before the 19 th century are commonly inaccurate.

\subsubsection{Reconstruction 1775 storm surge}

As for the 1717 storm, we needed to constrain the values of the relevant parameters to be used as input for the XBeach model. The 1775 event has rather detailed information available on the driving conditions (wind force) but little on the post-storm profile. The approach to fill in the missing gaps therefore differs from the approach used for the 1717 storm. Forward modelling starting from the wind force was used instead of inverse modelling.

The water levels, significant wave height and peak period all depend on the magnitude of the storm. The wind speeds that were measured in Zwanenburg, a land-based station south of Egmond, were used as stochastic variable. They were translated to North Sea wind speeds using the open water transformation (van Ledden et al., 2005) based on the Charnock's relation (Charnock, 1955), an empirical expression for aerodynamic roughness. These offshore wind speeds were used to estimate the wind-induced surge using the Weenink method (Weenink, 1958). The tide was estimated on the basis of water-level observations made at Katwijk during the period 1737-1739. The wave characteristics were estimated using the Sverdrup-Munk-Brettschneider growth curves (Holthuijsen, 2007). The median grain diameter was derived from the grain-size distribution of the storm-surge deposits (Cunningham et al., 2009). The palaeobathymetry was based on a combination of JARKUS data and sounding data (de Graaf et al., 2003), as for the 1717 scenario, assuming that the bathymetry did not change much over the period 1775-2011. The validity of this assumption is likely, in the light of a comparison of the recent bathymetry with a reconstruction of historical contour lines by Haartsen et al. (1997). For the construction of the palaeotopography, the 2007 data were used from the "Actueel Hoogtebestand Nederland" (AHN - Actual Elevation Database). The beach and the strong anthropogenic frontal dune were removed, assuming that the topography behind the dune resembles the topography in 1775 (before frontal dunes were under heavy anthropogenic influence). From this reconstructed bathymetry and topography, a characteristic transect was selected for further analysis.

\subsubsection{Probabilistic modelling 1775 storm surge}

The same XBeach model was used as for the 1717 storm, but with different boundary conditions and paramater settings. Unlike for 1717 , the goal was not inverse modelling the erosion profile but assessing what type of storm could have resulted in a surge and run up capable of depositing the shell beds that were exposed in the dune scarp following the 2007 storm surge. The $2 \%$ exceedance level of the run-up is assumed to be the level where the shell would have been deposited.

We find that the storm profile of the confidence interval of the run-up level includes the height of the storm-surge layer at $6.5 \mathrm{~m}$ (Fig. 4). Therefore, we assume that the shell deposits found can indeed be from the 1775 storm. Using the exceedance lines for run-up levels as calculated by Philippart et al. (1995), the associated storm surge has a 3/10000 per year exceedance probability.

\subsection{The storm surge of 21 November 1776}

This storm surge occurred only one year after the major storm surge of 1775. This storm surge is measured on several locations along the Dutch coast. We estimate that the storm of 1776 resulted in a storm surge approximately $0.2 \mathrm{~m}$ lower than the 1775 storm surge. This difference is based on the average of the differences of locations where both the 1775 and 1776 stations were recorded (van Malde, 2003).

The corresponding exceedance probability would be $8 / 10000$ per year, based on the probability distributions estimated by Philippart et al. (1995).

\section{An updated confidence interval for the $1 / 10000$ per year storm surge}

To improve the confidence interval associated with the extrapolation of the monitoring series of water levels that started in the late 19th century, we used a method comparable to the one developed by Van Gelder (1996). From the three new data points (water levels for 1717, 1775, 1776), the a posteriori distribution for the $1 / 10000 \mathrm{yr}$ storm surge can be created. The availability of estimates of the three highest annual water-level maxima of the 18th century implies that 

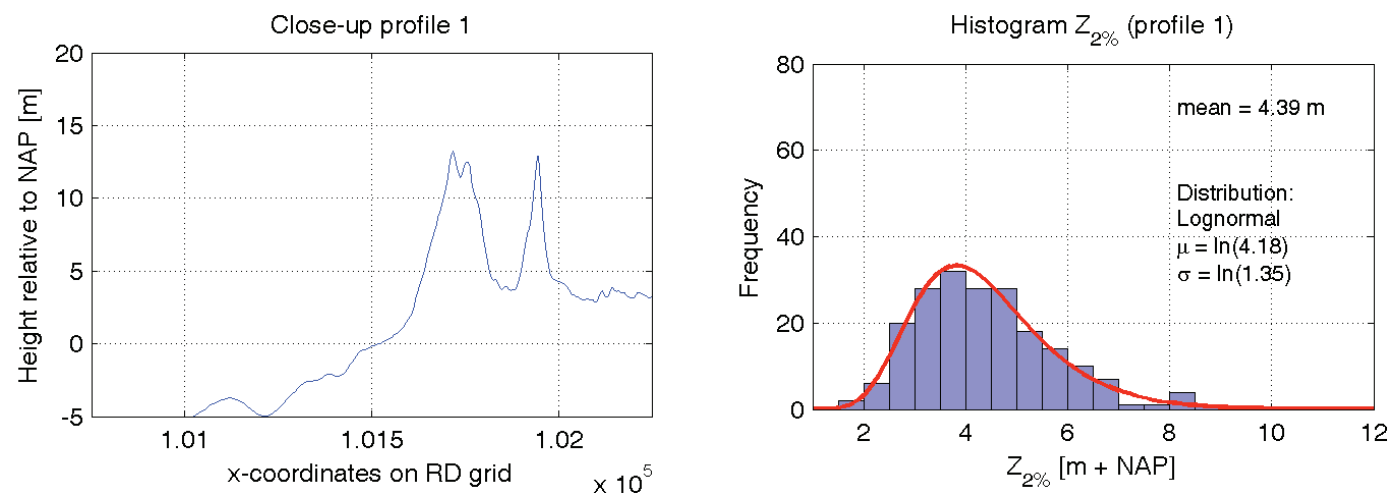

Fig. 4. Left panel: close-up bathymetry profile 1. Right panel: histogram Z2\% and best-fit distribution for profile 1.
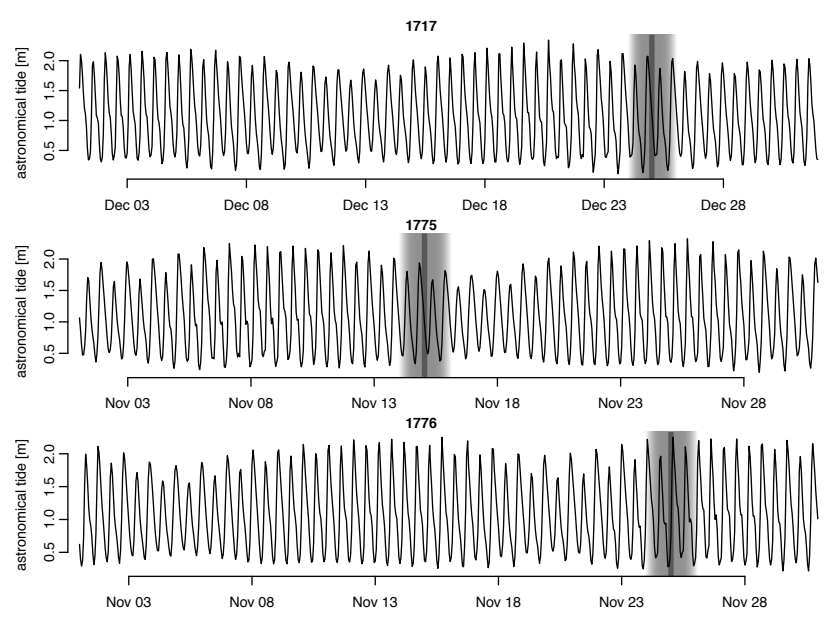

Fig. 5. Astronomical tide for the IJmuiden station during the storms of 1717, 1775 and 1776 (marked in grey).

the other $97 \mathrm{yr}$ must have had lower annual maxima than the 1717 storm surge. We used this censored information to create a new distribution for high-end storms along the northern part of the Holland coast.

As an a priori distribution two techniques can be used. The "peak over threshold" approach uses all values over a threshold (for example all water levels over $2 \mathrm{~m}$ ). A generalised pareto distribution (GPD) is then fit to these water levels (Eq. 1, see for example Coles (2001)). In Eq. (1) $x$ is the water level, $\mu$ is the location parameter, $\sigma$ the scale parameter and $\xi$ the shape parameter. The second approach is to use the "block maxima" approach (for example maximum water level per year. This distribution is the generalised extreme value distribution (GEV), formulated as Eq. 2, with the same parameters as Eq. 1). If the shape parameter is assumed to be 0 , then the generalised extreme value distribution simplifies to a Gumbel distribution (Eq. 3, Gumbel and Lieblein (1954)). Van den Brink et al. (2005) showed that the first two methods give comparable results for estimating the
$1 / 10000$ water level. We used the block-maxima approach in order to integrate the historical observations with the waterlevel monitoring series.

$$
\begin{aligned}
& F_{(\xi, \mu, \sigma)}(x)= \begin{cases}1-\left(1+\frac{\xi(x-\mu)}{\sigma}\right)^{-1 / \xi} & \text { for } \xi \neq 0, \\
1-\exp \left(-\frac{x-\mu}{\sigma}\right) & \text { for } \xi=0 .\end{cases} \\
& F_{(\xi, \mu, \sigma)}(x)=\exp \left(-\left[1+\xi\left(\frac{x-\mu}{\sigma}\right)\right]^{-1 / \xi}\right) \\
& F_{(\mu, \sigma)}(x)=e^{-e^{-(x-\mu) / \sigma}}
\end{aligned}
$$

The reconstruction in this study has resulted in new estimates for the magnitude of the three biggest storm surges in the 18th century. The characteristics of the storms are shown in Table 3. Using this information, we were able to constrain the confidence interval for the 1/10000 storm surge. Using the Gumbel method, the confidence interval decreased by $30 \%$ because the number of observations increased almost twofold.

For the generalised extreme value approach, with a free shape parameter, the confidence interval is much larger. The large confidence interval here is caused by the large standard error of the shape parameter. This can be seen in Fig. 6, which shows the records for Egmond, based on a combination of an inverse-squared-distance weight of the records from the IJmuiden station Noordersluis $(\leq 1981)$, IJmuiden Buitenhaven (>1981) and Den Helder.

Because two of the three storms from the 18th century have a lower observed return period than their estimated return period, the GEV fit results in a positive shape parameter. This positive shape also results in a higher estimate of the $1 / 10000$ per year water level $(6 \mathrm{~m}$ combined versus $4.6 \mathrm{~m}$ for the 20th century). Computations were done using the $\mathrm{R}$ software (R Development Core Team, 2009) with the ismev (Coles and Stephenson, 2010) package and a modified version (custom log-likelehood method for confidence bounds) of the fExtreme (Wuertz , 2009) package. 

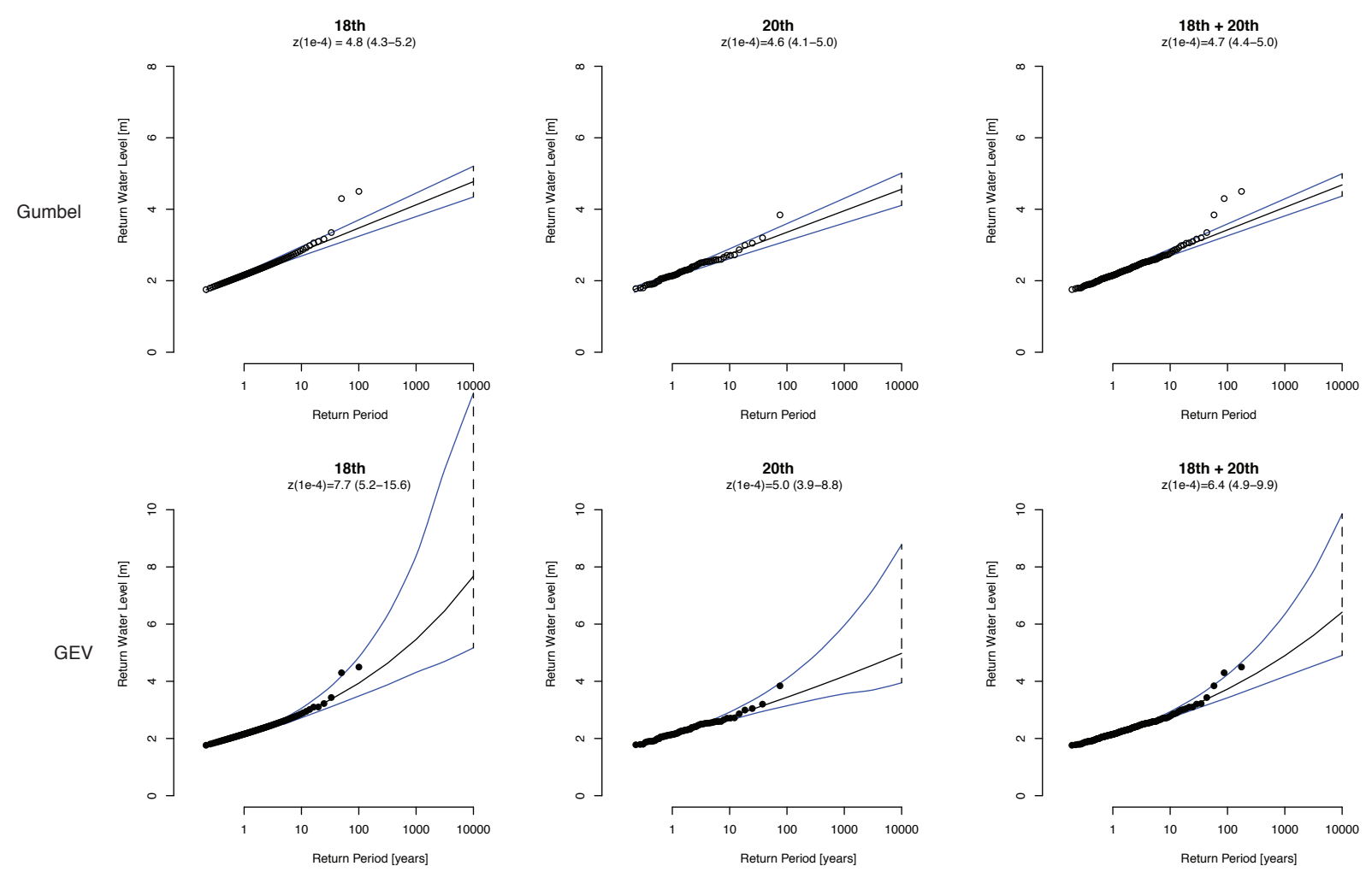

Fig. 6. Return level plot for the location Egmond for the period 1932-2010, 1700-1800 and the combined fit. The upper row represents a fit using the Gumbel distribution (Generalised Extreme Value distribution with $\xi=0$ ). The lower row represents a fit using the Generalised Extreme Value distribution using a free $\xi$ parameter. The circles represent observed (1932-2010) and estimated (1700-1800) water levels plotted against the observed return period. The black solid line represents the fitted return water level as a function of the return period. The outer blue lines follow the lower and upper bound of the $95 \%$ confidence interval. The vertical dashed line marks the confidence interval for the $1 / 10000$ per year water level.

Table 3. Estimated magnitude of the three largest storm surges of the 18 th century at the northern Holland coast.

\begin{tabular}{ccccl}
\hline Year & $\begin{array}{l}\text { Water } \\
\text { level }\end{array}$ & $\begin{array}{l}\text { Wave } \\
\text { height }\end{array}$ & $\begin{array}{l}\text { Wave } \\
\text { period }\end{array}$ & $\begin{array}{l}\text { Return } \\
\text { period }\end{array}$ \\
\hline 1717 & $3.1 \mathrm{~m}$ & $6.8 \mathrm{~m}$ & $10.4 \mathrm{~s}$ & $20 \mathrm{yr}$ \\
1775 & $4.6 \mathrm{~m}$ & $8.8 \mathrm{~m}$ & $13.9 \mathrm{~s}$ & $3300 \mathrm{yr}$ \\
1776 & $4.3 \mathrm{~m}$ & $8.5 \mathrm{~m}$ & $13.4 \mathrm{~s}$ & $1300 \mathrm{yr}$ \\
\hline
\end{tabular}

\section{Discussion}

The reconstructed water levels from the three storms are very high. They correspond to return periods of $20 \mathrm{yr}, 3300 \mathrm{yr}$ and $1300 \mathrm{yr}$ as derived from extrapolation of the monitoring records. Clearly, caution is required when combining these water-level return periods with the water levels measured by tide gauges. A number of possible causes of the apparent mismatch are inaccurate reconstruction and parametrisation, coincidence or change in storm climate.
It is difficult to give a solid estimate of the precision of these numbers, but based on the painter reliability and on the skill of the XBeach model (used with a lot of uncertain inputs), the standard error of the high-water estimates could be around $25 \%$ or $1 \mathrm{~m}$. So it could well be that the storms were in fact smaller than estimated here. Lower peak levels would of course result in a lower and narrower confidence region. It is difficult to give a proper estimate of the probability that three such large storms occurred in the 18th century, since such an assessment cannot be made solely on the basis of the 20th century monitoring series. It would be more informative to present uncertainties around the peak levels of individual storm surges, so that the return periods could also be presented with uncertainty intervals.

Research into changes in storminess over the periods of decades have not shown any clear indications that the coastal storminess has changed. Research into changes over the period of three centuries shows a decrease in storminess. This can be seen in relation to the stormy end of the Little Ice Age (e.g. Hass, 1996). Although higher storms were found in an earlier century than the last one, this research should not be used to conclude that the coastal storminess has decreased. 
The best approach to analyse changes in storminess over a multi-century timescale would be to construct a meta analysis using different types of records over a wider area combined.

\section{Conclusions and recommendations}

In this study we use historical record, a 3-D reconstruction of Egmond aan Zee and storm-surge layers in the dunes to reduce the size of the confidence interval associated with the $1 / 10000$ per year storm surge as determined by extrapolation of tide gauge monitoring series. This approach was successful in the procedure where the confidence interval was based on a Gumbel distribution, but not in the generalised extreme value approach, the estimate of the $1 / 10000$ per year water level is much higher and the confidence interval is slightly larger if the historical reconstructions are included with the generalised extreme value approach.

A logical step for further research would be to include storms from the other centuries where historical records are available. Also, the statistical method of including historical observations can still be improved, perhaps by applying a Bayesian approach to the combination of measurements, historical records and model simulations.

Although partially successful, our approach is less effective in increasing the confidence than the method used by Van den Brink et al. (2004) as the confidence interval depends on the number of (real and modelled) observations or datapoints. The maximum number of observations that can be extracted from history is limited by the length of history itself, which is much shorter than the return period of the design storm used in safety assessments of the Dutch coast.

Because the use of simulations is limited by physical knowledge and by assumptions that are put into the simulation model, other methods should also be examined. As discussed before, geological records can provide additional insight into storm surges that have left geological signatures, but from a statistical point of view these are hard to incorporate as the representative period is unknown. A last approach would be to look at other coasts and combine the distributions of multiple coasts into an estimate of the surge distribution.

Paintings and other images are a valuable data source in determining coastal change and, indirectly, storm-surge magnitude. Although the paintings are not always reliable, series of images covering extensive time periods provide a solid basis for reconstructing structural erosion. When combined with data from monitoring and measurement surveys, they may be very useful in many coastal areas in the developed world.

Acknowledgements. Pieter van Gelder, Petra Goessen, Jaap van Thiel de Vries, Hua Zhong, Dano Roelvink, Sophia Caires, Tabitha Post and Marcel Stive provided suggestions and comments. Rijkswaterstaat, the Koninklijke Bibliotheek (Royal Library), the Delft
University Kaartenkamer (Map Room), het Alkmaars Archief, Europeana, Hoogheemraadschap Hollands Noorderkwartier and the Nationaal Archief provided the datasets and historical records. This research received funding from the (European Community's) Seventh Framework Programme ([FP7/2007-2013]) under grant agreement number 202798, and the Ir. Cornelis Lely Foundation. Weeber architecten contributed to the layout of Fig. 2.

Edited by: P. Ciavola

Reviewed by: A. de Kraker and another anonymous referee

\section{References}

Author, Unknown: Extract van verschyde brieven, uyt Frederikstad, Hamborg, Embden, Hanover, Essens in Oost-Friesland, Bremen enz. Behelsende een verhaal, van de groote schade aldaar en elders veroorsaakt: door den schrikkelyken storm, en opgehoorden hoogen water-vloet op den 24. en 25. December 1717, Unknown Publisher, 1717a.

Author, Unknown: Nette aantekeningen volgens peylingen bevonden hoeveel de zomerpeilen in West-Vrieslandt zijn verschillende met ordinair dagelijks getij volzee, Map, $1717 \mathrm{~b}$.

Baart, F., van Gelder, P., de Ronde, J., van Koningsveld, M., and Wouters, B.: The effect of the 18.6 year lunar nodal cycle on regional sea level rise estimates, accepted, J. Coastal Res., 2011.

Bógaert, A.: De kersvloedt van den jare 1717 vermengt met de gedenkwaardigste vloeden sedert den algemeenen, Gerrit Bosch, Amsterdam, 1719.

Buisman, J.: Bar en boos: zeven eeuwen winterweer in de Lage Landen, Bosch \& Keuning, 1984.

Buisman, J. and Engelen, A. v.: Duizend jaar weer, wind en water in de lage landen. Dl. 1. Tot 1300, Van Wijnen, Franeker, 1995.

Buisman, J. and Engelen, A. v.: Duizend jaar weer, wind en water in de lage landen. D1. 2. 1300-1450, Van Wijnen, Franeker, 1996.

Buisman, J. and Engelen, A. v.: Duizend jaar weer, wind en water in de Lage Landen. Dl. 5. 1675-1750, Van Wijnen, Franeker, 2006.

Buisman, J. and Engelen, A. v.: Duizend jaar weer, wind en water in de Lage Landen. D1. 6. 1750-, Van Wijnen, Franeker, 2012.

Camuffo, D.: Le niveau de la mer à Venise d'après l'œuvre picturale de Véronèse, Canaletto et Bellotto, Rev. Hist. Mod. Contemp., 92-110, 2010.

Charnock, H.: Wind stress on a water surface, Q. J. Roy. Meteorol. Soc., 81, 639-640, 1955.

Coles, S.: An introduction to statistical modeling of extreme values, Springer Verlag, 69-71, 2001.

Coles, S. G. and Stephenson, A.: ismev: An Introduction to Statistical Modeling of Extreme Values, http://CRAN.R-project.org/ package $=$ ismev, $r$ package version 1.35, 2010.

Conrad, J.: Verhandeling over de Hondsbossche zeewering, $\mathrm{H}$. Coster en zoon, Alkmaar, 1864.

Cramer von Baumgarten, G. J. F.: De kersvloed van 1717; in gesprekken, ter herinnering van dien verschrikkelijken watersnood, voor 1817, Schierbeek, Groningen, 1817.

Cunningham, A., Wallinga, J., van Heteren, S., Bakker, M., van der Valk, B., Oost, A., and van der Spek, A.: Optically stimulated luminescence dating of storm surge sediments: a test case from the Netherlands, in: NCL Symposium Series, 6, 1-2, 2009.

Cunningham, A., Bakker, M., van Heteren, S., van der Valk, L., van der Spek, A. J. F., Schaart, D. R., and Wallinga, J.: Extracting 
storm-surge data from coastal dunes for improved assessment of flood risk, Geology, 39, 1063-1066, 2011.

de Graaf, H., Elberink, S. O., Bollweg, A., Brügelmann, R., and Richardson, L.: Inwinning droge JARKUS profielen langs Nederlandse kust, Tech. Rep. AGI-GAM-2003-40, Rijkswaterstaat, 2003.

de Haan, L.: Fighting the arch-enemy with mathematics, Stat. Neerl., 44, 45-68, 1990.

de Kraker, A.: Reconstruction of storm frequency in the North Sea Area of the Pre-industrial period, 1400-1625 and the connection with reconstructed time series of temperatures, Hist. Meteorol., 2, 51-69, 2005.

de Ruig, J.: Coastline management in The Netherlands: human use versus natural dynamics, Journal of Coastal Conservation, 4, 127-134, http://dx.doi.org/10.1007/BF02806504, 10.1007/BF02806504, 1998.

Deltacommissie: Rapport Deltacommissie. D1. 1. Eindverslag en interimadviezen, Staatsdrukkerij- en Uitgeverijbedrijf, 's-Gravenhage, http://repository.tudelft.nl/file/1219694/382018, 1960.

Gottschalk, M.: Stormvloeden en rivieroverstromingen in Nederland. Dl. 1. De periode voor 1400, 10, Van Gorcum, Assen, 1971.

Gumbel, E. and Lieblein, J.: Statistical theory of extreme values and some practical applications: a series of lectures, US Govt. Print. Office, 1954.

Haartsen, T., Ligtendag, W., and Steenhuisen, F.: Historische reconstructie dieptelijnen Nederlandse kust, Tech. rep., Rijksuniversiteit Groningen, Arctisch Centrum, 1997.

Hass, H.: Northern Europe climate variations during late Holocene: evidence from marine Skagerrak, Palaeogeogr. Palaeocl., 123, 121-145, 1996.

Holthuijsen, L.: Waves in oceanic and coastal waters, Cambridge Univ Pr, pp. 152, 2007.

Jakubowski-Tiessen, M.: Sturmflut 1717: die Bewältigung einer Naturkatastrophe in der frühen Neuzeit, 24, Oldenbourg Wissenschaftsverlag, 1992.

Jelgersma, S., Stive, M., and van der Valk, L.: Holocene storm surge signatures in the coastal dunes of the Western Netherlands, Mar. Geol., 125(1-2), 95-110, 1995.

Jevrejeva, S., Moore, J. C., Grinsted, A., and Woodworth, P. L.: Recent global sea level acceleration started over 200 years ago?, Geophys. Res. Lett., 35, doi:10.1029/2008GL033611, 2008.

KNMI: Antieke Reeksen, http://www.knmi.nl/klimatologie/ daggegevens/antieke_wrn/index.html, 2011.

Lang, A. and Homann, J.: DIE WEINACHTSFLUT VOM 25. DEZEMBER 1717: Erlũterungen zur Lichtdr. ausg. der Karte "Geographische Vorstellung der Jammerlichen Wasser-Flutt in Nieder-Teutschland" des J.B. Homann von 1718, Verlag Die Bake, Juist, 1963.

Macdonald, N., Werritty, A., Black, A., and McEwen, L.: Historical and pooled flood frequency analysis for the River Tay at Perth, Scotland, Area, 38, 34-46, 2006.

McInnes, R.: Art as a tool in support of the understanding of coastal change, Report, The Crown Estate, 2008.

Philippart, M., Pwa, S., and Dillingh, D.: De basispeilen langs de Nederlandse kust: de ruimtelijke verdeling en overschrijdingslijnen, Tech. rep., Rijkswaterstaat, 1995.

Pool, A. D.: Modelling the 1775 storm surge deposits at the Heemskerk dunes, Master's thesis, TU Delft, 2009.
R Development Core Team: R: A Language and Environment for Statistical Computing, R Foundation for Statistical Computing, Vienna, Austria, http://www.r-project.org, ISBN 3-900051-07-0, 2009.

Roelvink, D., Reniers, A., van Dongeren, A., de Vries, J. v. T., McCall, R., and Lescinski, J.: Modelling storm impacts on beaches, dunes and barrier islands, Coast. Eng., 56, 1133-1152, doi:10.1016/j.coastaleng.2009.08.006, 2009.

Schenk, P.: Kennemaria et Westfrisia vulgo et vernacul NoordHolland, tam in minores quam praecipuas ditiones..: edita per Nicolaum Visscher Amst: .., Schenk (Petrus), http://www. library.tudelft.nl/Tresor/webpages/TRL_5_3_1_15.html, 1740.

Smits, A., Tank, A., and Konnen, G.: Trends in storminess over the Netherlands, 1962-2002, Int. J. Climatol., 25, 1331-1344, doi:10.1002/joc.1195, 2005.

Specht, C.: Kaart van 't Graafschap Holland: naauwkeurig afgedeelt in zyne Heemraadschappen, Baljuwschappen en Waarden, nevens verscheide andere mindere afdeelingen en onderhorige landen alsmede de Heerlykheit Utrecht en het grootste gedeelte van Gelderlandt, Ottens, Amsterdam, http://www. library.tudelft.nl/Tresor/webpages/TRL_5_3_1_05.html, 1740.

van Brussel, T.: Naauwkeurige beschryving der twee voornaamste watervloeden van de XVIIIe eeuwe, in 1717 en 1775 ...; waarby gevoegd is een kort kronykje van alle watervloeden, van den zondvloed van Noach af, tot op deezen laatsten toe .., Bom (Gerrit), Amsteldam, 1776.

van Dantzig, D.: Economic decision problems for flood prevention, Econometrica, 24, 276-287, 1956.

van de Graaff, J.: Probabilistic design of dunes - an example from the Netherlands., Coast. Eng., 9, 479-500, 1986.

van den Brink, H., Können, G., Opsteegh, J., van Oldenborgh, G., and Burgers, G.: Improving $10^{4}$-year surge level estimates using data of the ECMWF seasonal prediction system, Geophys. Res. Lett., 31, L17210, doi:10.1029/2004GL020610, 2004.

van den Brink, H., Konnen, G., and Opsteegh, J.: Uncertainties in extreme surge level estimates from observational records, Philos. T. Roy. Soc. A., 363, 1377-1386, doi:10.1098/rsta.2005.1573, 2005.

van Gelder, P.: Bayesian analysis of extreme water levels along the Dutch coast using flood historical data, Stoch. Hydraul., 7, 243251, 1996.

van Gelder, P. H. A. J. M.: Statistical methods for the risk-based design of civil structures, Ph.D. thesis, Delft University of Technology, http://www.library.tudelft.nl/ws/search/publications/search/ metadata/index.htm?docname $=088270,2000$.

van Ledden, M., Westra, M. R., Groeneweg, J., Wenneker, I., and Scholl, O.: SWAN berekeningen ten behoeve van HR2006 voor de Hollandse Kust Rapportage Fase 1, Tech. Rep. 9P8603.A0, Royal Haskoning, 2005.

van Malde, J.: Historische Stormvloedstanden, Tech. Rep. 2003.08.1, Aqua Systems International, 2003.

Vautard, R., Cattiaux, J., Yiou, P., Thépaut, J., and Ciais, P.: Northern Hemisphere atmospheric stilling partly attributed to an increase in surface roughness, Nat. Geosci., 3, 756-761, 2010.

Weenink, M.: A Theory and method of calculation of wind effects on sea levels in a partly-enclosed sea, with special application to the Southern coast of the North Sea., Ph.D. thesis, Utrecht University, 1958. 
Wheeler, D., Garcia-Herrera, R., Wilkinson, C. W., and Ward, C.: Atmospheric circulation and storminess derived from Royal Navy logbooks: 1685 to 1750 , Climatic Change, 101, 257-280, doi:10.1007/s10584-009-9732-x, 2010.
WL | Delft Hydraulics: Dune erosion; Product 3: Probabilistic dune erosion prediction method, Tech. Rep. H4357/A1414, WL | Delft Hydraulics/Alkyon, 2007.

Wuertz, D.: fExtremes: Rmetrics - Extreme Financial Market Data, http://CRAN.R-project.org/package=fExtremes, R package version 2100.77, 2009. 